\title{
Shopping tourism with a focus on the clothing industry in relation to globalization
}

\author{
Tomáš Ric ${ }^{1, *}$, and Daniela Š́lková ${ }^{1}$ \\ ${ }^{1}$ Czech University of Life Sciences in Prague, Faculty of Management, Department of Trade and \\ Finance, Kamýcká 129, 16500 Prague, Czechia
}

\begin{abstract}
.
Research background: The paper deals with the connections between international tourism and shopping, and therefore the purchase of clothing in relation to consumers. In the last few years, shopping has become one of the factors determining tourist's decisions about choosing a travel destination. One-third of tourists have ever travelled just to buy clothes abroad. Such behaviour offers enormous economic potential for companies and the state economy. Shopping tourism is an integral part of globalization. Purpose of the article: The article's aim is to characterize the elements of consumer behaviour in the framework of shopping tourism when buying clothing products. In addition to consumer preferences, the aim is to characterize the main types of clothing products that travellers are interested in and the impact of this consumer behaviour on the globalization.

Methods: A questionnaire is compiled on the basis of stated hypotheses. The results will be evaluated using appropriate statistical methods such as the Kruskal-Wallis test, Spearman's correlation coefficient and categorical principal components analysis.

Findings \& Value added: Research has shown that the first group of preferred garments consists of local products at a higher price level produced in low quantity. The second type of product is low-cost garments produced at a high cost under conditions that do not correspond to the principles of sustainable development. The clothing industry impact on global sustainable development is largely negative. In this regard, we can talk about the negative impact of globalization. This is no different from tourism.
\end{abstract}

Keywords: Shopping tourism; Clothing Industry; Consumer Behaviour; Sustainable Development; Globalization

JEL Classification: $F 63 ; F 1 ; L 67$

\footnotetext{
${ }^{*}$ Corresponding author: rict@pef.czu.cz
} 


\section{Introduction}

Despite the industry's great economic potential, there are a relatively small number of articles that address the issue of shopping tourism with a focus on clothing and characterization of industry relations or consumer needs.

The term tourism refers to temporary travel across the borders of one's state. According to [1] and [2] travel should include elements of joy and pleasure. Tourism is primarily an activity or process of spending time in a place far from home to recreate, relax, have fun using commercial measures, services and products [3].

In the 1970s, there was a global boom in tourism [4], when it began to be the subject of research in the academic sphere. Tourism first became linked to sustainable development in the 1990s [5].

In 2018, tourism accounted for 3.3\% of global GDP at \$ 2.85 billion. The year-on-year increase compared to 2017 was $3.9 \%$ [6].

The cross-border number of tourists is expected to continue to grow at a rate of $3.3 \%$ year on year by 2030 . In nominal terms, there are 43 million more tourists each year with a total number of 1.8 billion cross-border trips in 2030 [7]. The prediction proves the economic potential of the industry. These predictions may seem to be outdated nowadays because of the Covid-19 pandemic situation. The growth trend of tourism alongside with restaurants and entertainment in 2020 is suspended by the crisis associated with COVID-19. The industries face large demand shock [8].

Definitions of tourism mostly omit shopping as a motivating or significant stimulating factor in tourism [9]. Many studies prove otherwise [9-11]. With a growing trend in the last decade, shopping has become a relevant part of the tourist value chain. Shopping is a determining factor influencing the choice of destination. In some cases, shopping is even a primary motivating factor $[3,10,12]$.

Based on research by [13], it is clear that $28 \%$ of passengers choose their destination for their shopping and fashion options.

Cohen [14] links shopping to the concept of sustainability, which is increasingly popular with the public and also has a significant impact on consumer decision-making [15]. The topic of sustainability is discussed in detail in the articles by Návrátilová et al. [16], Procházka et al. [17] and others.

Navrátilová et al. [16] confirm public knowledge of the term sustainable development. $91.4 \%$ of young respondents know the concept and $48.3 \%$ of respondents consider it important compared to $43.2 \%$ for whom it is not important.

Sustainable development covers three main areas: economic, environmental and social sustainability [17]. Sustainable behaviour and reducing impacts on the three main areas of sustainability can be observed at several levels of the article topic at all stages of the supply chain, both in tourism and the clothing sector [18]. All of these aspects influence sustainability globally. On the one hand, humanity is fighting textile waste, on the other hand, society still wants new products as described by Szafrańska et al. [19] in the field of food.

The article's aim is to identify the correlation between selected socio-demographic characteristics (gender, age) and actions connected to shopping and tourism (frequency of travel abroad, frequency of shopping). It is important to characterize the elements of consumer behaviour in the framework of shopping tourism when buying products of the clothing industry during tourism. Thus the correlation between the frequency of travel and shopping behaviour (visiting shops, purchase) is also identified. In addition to consumer preferences, the aim is to characterize the main types of clothing products that travellers are interested in. A partial goal is to relate the findings to a global scale. 


\section{Methods}

The research is based on the study of available literature and professional publications. Based on the research part, a consumer questionnaire was compiled to find out data on the relationship of individual consumer segments to shopping tourism. The questionnaire was distributed in electronic form. The minimum required number of respondents is 500, which according to Malhotra and Birks [20] ensures the validity of the data. The questionnaire was distributed at the Faculty of Business and Economics at the CULS in Prague with the help of students. They aimed to address the general public. The method of data collection may be the limit for the paper.

The questionnaire was divided into a total of 4 parts: demographic data of respondents, relationship to travel, relationship to fashion, relationship to buying clothes while travelling. The questionnaire used a combination of open, closed and semi-open answers using Likert's scales with a total of 30 questions. Only some of them were selected for the purposes of the article.

The data were evaluated by the statistical program SPSS.

The sample consists of 537 respondents: women $64.5 \%$, men $36.6 \%$. The average age of the respondents is 36.88 years. The youngest respondent was 14 years old while the oldest was over 74 years old. The median divides the group at the age of 34.5 years and the most frequent respondents are people aged 24.5 years. Respondents by age do not have a normal distribution. The average monthly income of the sample is CZK 23,249.5. The minimum is around CZK 5,000, while the highest revenues are above CZK 95,000. The data do not reach the normal distribution at a slope of 1.662. The median monthly income is CZK 25,000, which is close in value to the median income of Czech citizens in 2018 of CZK 27,719 (CZSO, 2018).

The most numerous groups are employees $40.4 \%$, followed by working students $22.9 \%$ and students without work $15.3 \%$. The fourth most common economic status is an entrepreneur with a share of $12.1 \%$.

Subsequently, null hypotheses were established, the validity of which was verified by appropriate statistical tests at the significance level $\alpha=0.05$. The hypotheses are:

$\mathrm{H}_{1}$ : Gender does not affect the frequency of travel abroad.

$\mathrm{H} 2_{0}$ : Gender does not affect the frequency of clothing purchases.

$\mathrm{H} 3_{0}$ : Frequency of travel does not affect the frequency of visits to unknown shops.

$\mathrm{H} 4_{0}$ : Frequency of travel abroad does not affect the frequency of clothing purchases.

$\mathrm{H} 5_{0}$ : Age of consumers does not affect clothing expenditure.

The Kruskal-Wallis test $(\mathrm{Q})$ used for $\mathrm{H} 1_{0}$ and $\mathrm{H} 2_{0}$ is a nonparametric test that is used for data for which a normal file distribution cannot be assumed. The formula for calculating the test criterion is:

$$
Q=\frac{12}{n(n+1)} \sum_{i=1}^{k} \frac{T_{i}^{2}}{n_{i}}-3(n+1)
$$

Spearman's correlation coefficient $\left(\mathrm{r}_{\mathrm{s}}\right)$ was chosen to analyze the relationship for the ordinal variables $\mathrm{H}_{3}$ and $\mathrm{H} 4_{0}$. The coefficient takes values in the interval $<-1 ; 1>$. The formula for calculating the Spearman correlation coefficient is:

$$
r_{s}=\frac{\sum_{i=1}^{n} x_{r i} y_{r i}-n \bar{x}_{r} \bar{y}_{r}}{(n-1) s_{x r} s_{y r}}
$$

Pearson's correlation coefficient was used for quantitative paired quantities $\mathrm{H} 5_{0}$. The coefficient takes values in the interval $<-1 ; 1>$. The prerequisites for using the methodology were met. The formula for calculating the test criterion is: 


$$
r=\frac{\sum_{i=1}^{n} x_{i} y_{i}-n \overline{x \bar{y}}}{(n-1) s_{x} s_{y}}
$$

Categorical principal components analysis was used to define the main demanded types of clothing. Respondents were to identify with a given type of clothing product on the Likert scale. The statements were as follows: (1) I prefer expensive clothes, (2) I prefer expensive and quality clothes, (3) I prefer expensive and unique clothes, (4) I prefer quality in low quantities, (4) I prefer cheap clothes in higher quantities, (5) I prefer fashionable clothes.

The methods used are described in detail by Řezánková [21].

The main components, i.e. the two directions of demanded products, are put into context with sustainable development based on comparison with the authors on the topic of sustainability of the discussants.

\section{Results and Discussion}

Based on the research, it was found that respondents travel abroad the most 3.5 times in one calendar year, up to half of the cases. Less than $30 \%$ of respondents travel abroad 1-2 times a year. The remaining $20 \%$ travel abroad 8 or more times a year. Respondents spend an average of CZK 33,022.9 per year on travel, which is less than CZK 2,758 per month to simplify comparisons. If we compare this value with the average monthly income, travel expenses account for $11.9 \%$ of total consumer expenses.

UNWTO [10], Timothy [3] and Trobe et al. [12] state that shopping for clothes can be the primary motive for travelling. The results of the survey also prove this. $28.5 \%$ of respondents went abroad at some point in their lives just to buy clothes.

$29.5 \%$ of tourists plan to visit a clothing store on their travels, while $63.5 \%$ do not plan such an activity. The remaining sample of the respondent does not know. The finding corresponds to a previous survey by Booking.com [13]. The finding makes it possible to extend the findings of the World Travel \& Tourism Council [6] by the size of the tourist market motivated by the factor of buying clothes. That would be $\$ 0.94$ billion, calculated at fair value in 2018.

Table 1. Result of statistical testing of null hypotheses

\begin{tabular}{|c|c|c|c|c|c|}
\hline $\begin{array}{l}\text { Hypo- } \\
\text { thesis }\end{array}$ & Method & $\begin{array}{c}\mathrm{P}- \\
\text { value }\end{array}$ & $\begin{array}{l}\text { Corre- } \\
\text { lation }\end{array}$ & Result & Alternative hypothesis \\
\hline H10 & $\begin{array}{l}\text { Kruskal-Wallis } \\
\text { test }\end{array}$ & 0.414 & - & $\begin{array}{l}\text { Failure to reject the null } \\
\text { hypothesis }\end{array}$ & - \\
\hline $\mathbf{H} 2_{0}$ & $\begin{array}{l}\text { Kruskal-Wallis } \\
\text { test }\end{array}$ & 0.000 & - & $\begin{array}{l}\text { Acceptance of } \\
\text { alternative hypothesis. }\end{array}$ & $\begin{array}{l}\mathrm{H} 2_{1} \text { : There is a difference in } \\
\text { the frequency of shopping for } \\
\text { men and women. }\end{array}$ \\
\hline $\mathbf{H 3}_{\mathbf{0}}$ & $\begin{array}{l}\text { Spearmen } \\
\text { coefficient }\end{array}$ & 0.000 & 0.349 & $\begin{array}{l}\text { Acceptance of } \\
\text { alternative hypothesis. }\end{array}$ & $\begin{array}{l}\text { H3 }{ }_{1} \text { : People who often travel } \\
\text { abroad also visit unknown } \\
\text { shops more often. }\end{array}$ \\
\hline H40 & $\begin{array}{l}\text { Spearmen } \\
\text { coefficient }\end{array}$ & 0.000 & -0.236 & $\begin{array}{l}\text { Acceptance of } \\
\text { alternative hypothesis. }\end{array}$ & $\begin{array}{l}\mathrm{H} 4_{1} \text { : The frequency of } \\
\text { travelling abroad affects the } \\
\text { frequency of buying clothes. }\end{array}$ \\
\hline H50 & $\begin{array}{l}\text { Pearson } \\
\text { correlation } \\
\text { coefficient }\end{array}$ & 0.148 & -0.063 & $\begin{array}{l}\text { Failure to reject the null } \\
\text { hypothesis }\end{array}$ & - \\
\hline
\end{tabular}


Table 1 shows the result of statistical testing of null hypotheses. Men and women go abroad equally often $\left(\mathrm{H}_{1}\right)$, so it is not necessary to focus on marketing for both. Interesting is the difference in the frequency of shopping for women and men $\left(\mathrm{H} 2_{0}\right)$. Men shop more often by $23.2 \%$. A positive correlation is found between the visit to new shops and the frequency of travel $\left(\mathrm{H} 3_{0}\right)$. Hence the need for small business units to promote their services in tourist places. There is a negative correlation between the frequency of trips abroad and the purchase of clothing. Those tourists who travel more often have less need to look for clothing purchases $\left(\mathrm{H}_{4}\right)$. The age of consumers does not affect expenditure on clothing $\left(\mathrm{H} 5_{0}\right)$. However, it is necessary to attach different importance to different age categories in the communication of ethical clothing, which converts into purchases. Younger people tend to be more informed about sustainability, while older age people need to be educated.

Part of the evaluation of the data obtained in the survey was a Categorical principal components analysis focused on the type of clothing that is most sought after by consumers.

The model of Categorical principal components analysis (Table 2) determined that two main important components are explaining the fact of $63.1 \%$.

In the file, the greatest dependence occurs between the following statements: I prefer expensive clothes, I prefer expensive unique clothes, I prefer fashionable clothes, I prefer quality in a smaller number of pieces. These statements characterize the first component.

On the contrary, the least correlation occurs in claims I prefer more cheap clothing to other claims. Cheap and highly quantitative clothing, on the other hand, is characteristic of the second component, for which there is a significant correlation. The influence of individual statements is detailed in Table 2.

Table 2. Influence of individual variables on components in the categorical analysis of the main components

\begin{tabular}{lcc}
\hline & \multicolumn{2}{c}{ Dimension } \\
\hline I prefer expensive clothes & $\mathbf{1}$ & $\mathbf{2}$ \\
I prefer expensive and quality clothes & 0,640 & 0,355 \\
I prefer expensive and unique clothes & 0,770 & $-0,215$ \\
I prefer quality clothes in low quantities & 0,791 & 0,173 \\
I prefer cheap clothes in higher quantities & 0,709 & $-0,274$ \\
I prefer fashionable clothes & $-0,234$ & 0,873 \\
\hline
\end{tabular}

The second component clearly defines the so-called fast fashion industry, offering cheap clothing often produced in developing countries. We can assume the importance of global known brands as described by Kral and Janovska [22] on a positive purchase decisions. Production is accompanied by a minimum standard of living for workers, damage to the land by intensive agriculture and the ignorance of the circular economy. Turker and Altuntas [18] discuss the individual impacts and actions of such companies. Gardas [15] deviates from the general view that the decision lies with consumers and defines the important position of the public sector and the need for regulations that contribute to positive development. Thus, the part of respondents buying high-cost clothing would lose the opportunity to purchase an unethical product.

\section{Conclusion}

Shopping alone and shopping for clothes while travelling offers huge economic potential. Almost $30 \%$ of respondents went abroad at some time in their lives just to buy clothes, and 
the same number of respondents plan to visit a clothing store during their travels. The commercial sector needs to examine consumer perceptions support for set business goals.

Gender differences in the frequency of travel abroad are minimal. The difference is in the frequency of shopping for clothes, which men buy more often. Tourists have a greater tendency to visit unknown shops, which must be introduced to them well in advance.

We consider the negative connection between the frequency of travelling abroad and the frequency of shopping for clothes to be an interesting finding. The findings can be interpreted in many ways, such as other values of life, oversaturation of supply, etc. For shopping behaviour in the area of the frequency of clothing purchases, age is not a significant variable that would affect shopping behaviour.

In terms of maximizing sales of clothing companies, it is necessary to focus on two main product directions. The first of them should be focused on unique clothing with high added value in the form of design work and quality at a higher price level. The second type of product is a cheap product in high quantity that saturates a need that cannot be met at home. We do not recommend combining both types of product in one business concept, as consumers are oriented in one direction or the other.

\section{References}

1. Burkart, A.J., Medlik, S. (1981). Tourism: past, present and future. Retrieved from: https://books.google.hr/books?id=7lmAAAAAMAAJ

2. Murphy, P.E. (2012). Tourism : a community approach. UK : Routledge

3. Timothy, D.J. (2005). Shopping, tourism retailing and leasure. UK : Channel View Publications.

4. Crouch, G.I., Ritchie, J.R.B. (1991). Tourism, competitiveness, and societal prosperity. Journan of Business Research, 44(3), 137-152.

5. Higgins-Desbiolles, F. (2018). Sustainable tourism: sustaining tourism or something more ?. Tourism Management Perspectives, 25, 157-160.

6. World Travel \& Tourism Council (2019). Travel \& Tourism Impact 2019. Retrieved from :

https://wttc.org/Research/EconomicImpact/moduleId/1445/itemId/91/controller/DownloadRequest/action/QuickDownload

7. Tovmasyan. G.R. (2017). Fashion industry and shopping tourism. Aктуальные проблемы гуманитарных и естественных наук, 1-3, 80-83.

8. Del Rio-Chanona, R.R., Mealy, P., Pichler, A., Lafond, F., Farmer, D. (2020). Supply and demand shocks in the COVID-19 pandemic: an industry and occupation perspective. $1-38$.

9. Timothy, D.J., Butler, R.W. (1995). Cross-border shopping a north american perspective. Annals of Tourism Research, 22(1), 16-34.

10. UNWTO. (2014, May 14). Global report on shopping tourism. Retrieved from: https://www.unwto.org/archive/middle-east/publication/global-report-shoppingtourism

11. Wakefield, K.L., Baker, J. (1998). Excitement at the mall : determinants and effects on shopping response. Journal of Retailing, 74(4), 515-539.

12. Lee, J.S., Choi, M. (2020). Examining the asymmetric effect of multi-shopping tourism attributes on overall shopping destination satisfaction. Journal of Travel Research, 59(2), 295-314. 
13. Booking.com. (2018, September 18). Retail therapy: why we're travelling for fashion. NZ Herald. Retrieved from: https://www.nzherald.co.nz/travel /news/article.cfm?c_id=7\&objectid=12127369

14. Cohen, S.A., Prayag, G., Moital M. (2014). Consumer behaviour in tourism: concepts, influences and opportunities. Current Issues in Tourism, 17(10), 872-909.

15. Gardas, B.B., Raut, R.D., Narkhede, B. (2018). Modelling the challenges to sustainability in the textile and pparel (T\&A) sector : a deplhi-DEMATEL approach. Sustainable Production and Consumption, 15, 96-108.

16. Navratilova, M., Beranova, M., Hrbek I., Broz D. (2019). Alternative food networks as a toll influencing young consumers' purchasing decision-making. In : Tomsik, K. (Eds.), Proceedings of the Agrarian Perspectives XXVIII (pp. 226-232). Prague: Agrarian Perspectives Series.

17. Prochazka, J., Cejopva, I., Smekalova, T. (2019). Economic results of social farms in the czech republic. In : Tomsik, K. (Eds.), Proceedings of the Agrarian Perspectives XXVIII (pp. 208-2017). Prague : Agrarian Perspectives Series .

18. Turker, D., Altuntas, C. (2014). Sustainable supply chain management in the fast fashion industry: an analysis of corporate reports. European Management Journal, 32(5), 837849.

19. Szafranska, M., Krasnodębski, A., Kapsdorferova, Z. (2020). Level of financial literacy and food waste in polish households. AGRIS on-line papers in Economics and Informatics, 12(1), 99-109.

20. Malhotra, N. (2007). Marketing research: an applied approach. London: Pearson Eduation.

21. Reznakova, H. (2007). Analýza dotazníkových šetření. Pruhonice: Professional Publishing.

22. Kral, P., Janoskova, K. (2020). Consumer perception of global branded products quality. In : Kliestik, T. (Eds.) 19th International Scientific Conference Globalization and Its Socio- Economic Consequences - Sustainability in the Global-Knowledge Economy (Article Number 01018). Rajecke Teplice: SHS Web of Conferences. 